FM-2030 (1989) Are You a Transbuman? Monitoring and Stimulating Your Personal Rate of Growth in a Rapidly Changing World. Warner Books. 227 p.

Fukuyama, F. (2012) The Future of History: Can Liberal Democracy Survive the Decline of the Middle Class? Foreign Affairs, no. 91(1), pp. 53-61.

Gardner, M. (1970) The fantastic combinations of John Conway's new solitaire game «life». Scientific American, no. 4, pp. 120-123.

Hughes, J. J. (2012) The politics of transhumanism and the techno-millennial imagination, 1626-2030. Zygon, vol. 47, no. 4, pp. 757-776.

Huxley, J. (1957) New Bottles for New Wine. L. : Chatto \& Windus. 320 p.

Ichbiah, D. (2005) Robots: from science fiction to technological revolution. N. Y., Harry N. Abrams. $540 \mathrm{p}$.

McClelland, N. C. (2010) Encyclopedia of Reincarnation and Karma. Jeff., New Carolina, London : McFarland and Co. Inc. Publ. 321 p.

Sharon, T. (2014) Human Nature in an Age of Biotechnology: The Case for Mediated Posthumanism. Dordrecht, The Netherlands: Springer. $241 \mathrm{p}$.

Ranisch, R. and Sorgner, St. L. (eds.) (2014) Post-and Transhumanism: An Introduction. Frankfurt am Main (et al.): Peter Lang. 313 p.

Vita-More, N. The Transhumanist Culture. Natasha Vita-More, PhD. [online] Available at: http://www.natasha.cc/transhumanistculture.htm (access date: 20.05.2017).

Submission date: 18.09.2017.

Иуков Валерий Андреевич - доктор философских наук, профессор, директор Института фундаментальных и прикладных исследований Московского гуманитарного университета, заслуженный деятель науки Российской Федерации, академик Международной академии наук (IAS, Инсбрук). Адрес: 111395, Россия, г. Москва, ул. Юности, д. 5. Тел.: +7 (499) 374-75-95. Эл. aApec: v-lukov@list.ru

Lukov Valeriy Andreyevich, Doctor of Philosophy, Professor, Director, Institute of Fundamental and Applied Studies, Moscow University for the Humanities; Honoured Scientist of the Russian Federation; Full Member, International Academy of Sciences (Innsbruck). Postal address: 5, Yunosti St., Moscow, Russian Federation 111395. Tel.: +7 (499) 374-75-95. E-mail: v-lukov@list.ru

DOI10.17805/zpu.2017.4.12

\title{
Трансгуманистические представления о человеке в современном антропологическом дискурсе
}

\author{
В. А. Долин \\ БЕЛГОРОДСКИЙ ЮРИДИЧЕСКИЙ ИНСТИТУТ МИНИСТЕРСТВА ВНУТРЕННИХ ДЕЛ \\ РОССИЙСКОЙ ФЕДЕРАЦИИИ ИМ. И. Д. ПУТИЛИНА
}

В статье исследуются философско-антропологические основания трансгуманизма и дается оценка их значения для сциентистской антропологии и современного антропологического дискурса в целом. Методологической основой анализа выступает диалог платоновской и аристотелевской традиций в философской антропологии, а также триада «структура - функционирование - развитие».

Философские основания трансгуманизма сформулированы в трех тезисах: человек есть разум; человек есть существо открытое, способное изменить собственную природу; ко- 
нечная цель изменения человека - достижение состояния сверхчеловека. Тезисы оцениваются с биоконсервативных позиций.

В целом для трансгуманизма человек есть разум, который может и должен изменить себя (технологическими средствами). Подобное понимание человека есть сциентистский платонизм. Отрицание трансгуманизмом представлений о биосоциальной природе человека фундируется стремлением отвергнуть центральный тезис аристотелизма в философской антропологии: человек есть двуединство души и тела, которые неравноценны, но одинаково необходимы для формирования природы человека.

В контексте сциентистской антропологии трансгуманизм выступает как принципиальный оппонент биоконсерватизма, который стремится сохранить «естественного человека». В современном антропологическом дискурсе трансгуманизм представляет собой диалектическое возвращение сциентистско-метафизического платонизма русского космизма. Вероятно, что и в данном случае технократический оптимизм окажется не вполне обоснованным.

В концептуальном аспекте трансгуманистическая антропология есть «рафинированный платонизм», отвергающий аристотелистскую традицию постижения человека. Возникновение трансгуманизма в современном антропологическом дискурсе является закономерным. Обосновывается вывод о возможности критического пересмотра антропологических оснований трансгуманизма. Его основой станет продуктивный и взаимообогащающий диалог трансгуманистической антропологии с аристотелистской традицией в понимании человека.

Ключевые слова: трансгуманизм; биоконсерватизм; природа человека; сущность человека; платонизм; аристотелизм; сверхчеловек; NBIC-конвергенция; конвергентные технологии; постчеловек

\section{ВВЕАЕНИЕ}

\онцептуальное понимание человека является одной из важнейших проблем фило—софии, которая формирует философскую антропологию в ее широком понимании. Каждый этап исторического развития философии открывает новые аспекты названной проблемы. В современном антропологическом дискурсе интенсивно развиваются сциентистские направления, тяготеющие к двум базовым вариантам трансгуманизму (Глобальное будущее 2045 ..., 2013) и биоконсерватизму (Человек и его будущее ..., 2012). Возникновение и развитие данных направлений обусловлено прогрессом новейших (NBIC) технологий и нацелено на оценку перспектив влияния $N B I C$-конвергенции на будущее человека.

Объектом данной статьи является трансгуманизм как направление сциентистской антропологии, выступающее за радикальное сближение человека и $N B I C$-технологий, конечным результатом которого станет технологическое усовершенствование природы человека. Предмет статьи - рассмотрение философских оснований трансгуманистических представлений о человеке в контексте современного антропологического дискурса. Последний понимается в фукольдианском смысле, т. е. как двуединство антропопрактик и фундирующих их теорий.

Раскрытие предмета статьи предполагает рассмотрение двух задач: во-первых, выделение и анализ философско-антропологических оснований трансгуманизма, во-вторых, оценка их значения в контексте сциентистской антропологии и современного антропологического дискурса в целом. Результатом проведенного исследования станет, с одной стороны, оценка закономерности возникновения трансгуманизма в современном антропологическом дискурсе, с другой - прогноз перспектив его дальнейшего развития.

Выделим и проанализируем философско-антропологические основания трансгуманизма (первая задача). На основе методологической триады «структура - функцио- 
нирование - развитие» названные основания возможно выразить в трех дедуктивно связанных тезисах.

\section{ТЕЗИС ПЕРВЫЙ}

В первом тезисе человек отождествляется с разумом или его отдельными способностями. Аанное утверждение возможно выразить более четко: человек - это разум. Например, А. И. Аубровский усматривает «стратегическое преимущество» трансгуманистического преобразования в том, что оно «...гарантирует сохранение и развитие человеческого разума...» (Аубровский, 2013: 244). А в качестве главной опасности современного экологического кризиса и других глобальных проблем современности называет то, что «...вместе с жизнью будет уничтожен и человеческий разум» (там же). Аля А. Ю. Нестерова «фундаментальное свойство человека... это рефлексия...» (Нестеров, 2013: 183), т. е. одна из способностей разума. В этой связи человеческое тело «...выступает как некий “переносчик” личности, материальная ограда для внутреннего мира...» (Барышников, 2013: 215-216).

Предваряя осмысление значения данного тезиса, необходимо сделать уточнение относительно используемой терминологии. Если исходить из кантовского тезиса о различении природы и сущности человека как сущего и должного соответственно, то постулат «человек есть разум» раскрывает сущность человека. Но поскольку представители трансгуманизма не всегда разграничивают содержание двух понятий, в дальнейшем изложении они будут рассматриваться как синонимы.

Тезис «человек есть разум» отвечает на вопрос «что есть человек?» и представляет собой сциентистский вариант возврата к одному из центральных тезисов антропологии платонизма: «...человек - это душа» (Платон, 1990: 259). По меткому выражению А. Койре, «душа - вот заглавное слово платоников и в конечном счете средоточие платоновской философии» (Койре, 1985: 59; курсив источника. - В. А.). По отношению к телу душа в платонизме рассматривается «как рулевой на корабле»: она правит телом, но от него не зависит (дуализм). В контексте антропологии платонизма движение «от тела к разуму» - вполне закономерный ход мысли (Щербаков, 2016). В результате складывается парадоксальная ситуация: сциентизм, традиционно рассматривающий человека как двуединство тела и разума (аристотелизм), понимает человека как разум (платонизм).

Но поскольку человек остается двуединством души и тела, он онтологически обделен (тезис о «биологической недостаточности», критикуемый оппонентами трансгуманизма (Желнин, 2016)). Например, для П. Н. Барышникова человеческое тело есть «...ветхая оболочка устаревшего человечества» (Барышников, 2016: 216). А. И. Аубровский среди негативных свойств природы человека называет «...неуемное потребительство, агрессивность к себе подобным, чрезмерные эгоистические устремления» (Аубровский, 2013: 238). Согласно А. Ю. Нестерову инерционный сценарий развития человечества лишен перспективы: «...эволюция будет следовать принципу аналогии, подчиненному корысти и эгоизму» (Нестеров, 2013: 190).

Иначе говоря, в трансгуманизме наличие у человека тела осознается как угроза его исключительности (Ж.-М. Шеффер). Выражаясь метафорически, «проклятье плоти» приковывает человека к несовершенной земле, не давая расправить «платоновские крылья» (Ж. Аелёз) и воспарить к небесам человеческого совершенства. Налицо параллели с платоновским пониманием души как «узницы тела»: «...душа туго-натуго связана в теле и прилеплена к нему, она вынуждена рассматривать и постигать сущее 
не сама по себе, но через тело, словно бь через решетки тюрьмь, и погрязает в глубочайшем невежестве...» (Платон, 1993: 39; курсив мой. - В. А.).

В содержательном аспекте тезис трансгуманистической антропологии «человек есть разум» есть ответ на вопрос о сущности (природе) человека. Однако в явном виде данное утверждение не формулируется. Вопрос о причинах данного парадокса будет обсуждаться в статье позднее.

Сведение человека к разуму (или его отдельным способностям) правомерно рассматривать как «бедное понимание» природы человека, фундированное дуалистическим пониманием последнего. П. С. Гуревич справедливо отмечает: «Попытка через разум раскрыть целостность человека оказалась химеричной. У человека есть страсти, воображение, воля. Они также могут претендовать на особую роль в авантюре человеческого преображения» (Гуревич, 2013: 106). Ауализм противоположностей в человеке неоднократно встречается в истории философии (гностицизм, 3. Фрейд, М. Шелер). По аналогии с оценкой М. Бубером антропологии М. Шелера, правомерно утверждать, что предметом трансгуманизма является «больной человек, отрезанный от мира» (Бубер, 1995: 226), но, в отличие от представлений М. Шелера, раздваивающийся между телом и разумом. Основанием для переноса по аналогии признака, выделяемого М. Бубером, является дуализм и шелеровской, и трансгуманистической антропологии.

Ф. Фукуяма, размышляя о специфике человеческого сознания, выделяет четыре его характеристики: «человеческий разум, человеческий язык, человеческий нравственный выбор и человеческие эмоции» (Фукуяма, 2004: 241-242). Очень важно, что не просто разум, язык, нравственный выбор и эмоции, а с антитрансгуманистическим уточнением - человеческий (ие). Также подчеркивается, что «мы - сложные целые, а не просто сумма частей» (там же: 243), поэтому найти единственное качество, обусловливающее целостность человека ( «фактор X»), невозможно (концепция «богатой природы человека»).

Утверждения идеологии трансгуманизма о том, что ее принципами являются «высокая духовность, высокая культура, высокая этика, высокая наука, высокие технологии» (Нестеров, 2013: 189), не изменяют ситуацию: понимание человека остается одномерным по причине крайностей фундирующего его дуализма. В итоге «частичный человек» трансгуманизма отчужден дважды: сначала концептуально, а затем праксеологически, поскольку теряет свою качественную определенность как биосоциальное существо. «Авойное отчуждение» человека в трансгуманизме смягчает лишь то, что в праксеологическом аспекте оно пока еще не стало реальностью.

\section{ТЕЗИС ВТОРОЙ}

Однако для трансгуманизма подобные выводы не характерны. Более того, «бедное понимание» природы человека обосновывает второй тезис трансгуманистической антропологии: человек есть существо открытое, способное изменить собственную природу. Или, в краткой формулировке: «человек - не раб своей природы» (Нестеров, 2013: 192). Среди возможных направлений эволюционного движения человека называются: преобразование личности в «очень сложную файловую структуру» или «модель перехода ментальных процессов в физические» посредством загрузки сознания в глобальную сеть (Барышников, 2013: 213-214); «преодоление биологической обусловленности человеческого существа» (Аёмин, 2013: 198); создание «качественно нового разума через симбиоз белковых и электронных носителей» (Назаретян, 2013: 47; 
курсив источника. - B. А.); путь «воплощения разума и социальной индивидуальности в небиологической самоорганизующейся системе» (Аубровский, 2013: 243).

С формально-логических позиций второй тезис трансгуманизма отвечает на вопрос «как изменяться человеку?» Однако фактически он объединяется с вопросом «थто есть человек?» (первая задача статьи). Выделенная двойственность интерпретации возвращает к парадоксу, выявленному ранее: утверждение о разумной природе (сущности) человека является одним из краеугольных камней трансгуманистической антропологии, но в явном виде, т. е. как дефиниенс понятия «природа (сущность) человека», не формулируется.

Разрешение парадокса связано с процессуально-динамическим, антиэссенциалистским пониманием природы человека в трансгуманизме, соответствующим неклассическому стилю философствования. Например, для И. В. Аёмина «человек это способность к трансцендированию сущностных параметров своей “природы” ” (Аёмин, 2013: 201). М. Н. Эпштейн с религиозно-философских позиций предлагает концепцию «кенотической природы человека» как «...его способности к самотрансценденции, перенесению своей сущности в нечто радикально отличное от себя» (Эпштейн, 2009: 93; курсив мой. - В. А.) Развивая концепцию, М. Н. Эпштейн предлагает теорию интеллектуальных эстафет: «речь идет о творческой әстафете, передаваемой Богом человеку, а человеком - искусственному разуму» (там же: 93). Аналогично кеносису Бога «...люди истощают себя в своих творениях, мыслящих машинах, чтобы передать им свою человечность, способность мыслить, свою мечту о бессмертии, всезнании и всемогуществе» (там же: 104). Подобное понимание природы человека правомерно охарактеризовать как технологический антиэссенциализм.

Вместе с тем в трансгуманизме существует натуралистически-эссенциалистское понимание природы человека А. И. Аубровского: природа человека биосоциальна, но с фундаментальной биологической основой (Аубровский, 2013: 237-238). Противоречивое сосуществование в одном дискурсе эссенциалистского и антиэссенциалистского понимания природы человека возможно объяснить тем, что для трансгуманизма метафизические размышления о природе (сущности) человека вторичны по отношению к тезису о возможности ее изменить. Иначе говоря, непринципиально, ито есть человек, важнее, как его изменить. И действительно, натуралистически-эссенциалистское понимание человека формулируется автором после тезиса о необходимости изменения природы человека.

Оценивая тезис об открытости природы человека изменениям, следует подчеркнуть, что трансгуманизм неслучайно выступает с позиций индетерминизма в понимании человека. Если «человек - это ничто» (Ж.-П. Сартр), не имеющий «ни определенного места, ни определенного образа, ни особой обязанности» и образующий «четвертый мир» мироздания (Аж. Пико делла Мирандола), то это определяет возможность любых его технологических преобразований. Подобный радикальный вариант понимания открытости природы человека в трансгуманизме есть закономерное следствие индетерминистской посылки.

В данном контексте авторы программных произведений биоконсерватизма (Хабермас, 2002; Фукуяма, 2004) закономерно возвращаются к практически забытой проблеме природы человека, а И. В. Черникова рассматривает ее сохранение как глобальную проблему современности (Черникова, 2016). Как справедливо отмечает Б. Матур, «...нам запрешено повторять ловкий ход Сартра, который определяет человека через свободное существование, вырывающееся из природы, лишенной каких 
бы то ни было значений, поскольку мы наделили все квазиобъекты ${ }^{1}$ действием, волей, значением и даже речью» (Матур, 2006: 219; курсив мой. - В. А.). Трансгуманистическое понимание человека как внеприродного существа ( «титанизм») объективно необходимо как основание для последующих выводов. Поэтому трансгуманизм в вопросе об открытости природы человека изменениям предлагает идти дальше, ведь «прогресс не остановить» (А. П. Назаретян).

\section{ТЕЗИС ТРЕТИЙ}

Третий тезис понимания человека в трансгуманизме утверждает, что конечная цель изменения человека - достижение состояния сверхчеловека. Аанное утверждение есть результат усиления второго тезиса: человек не только может, но и должен трансформировать собственную природу (традиция Ф. Ницше - Ж. Аелёза). Ради сохранения самого главного в человеке - его разума - от надвигающегося экологического кризиса и иных катаклизмов предлагается сценарий «кибернетического бессмертия», предполагающий перенос сознания и личности на альтернативный носитель, т. е. в небиологическую систему (Аубровский, 2013: 239; Нестеров, 2013: 190).

Третий тезис трансгуманизма отвечает на вопрос: «куда двигаться человеку?» В общем виде траектория движения такова: человек - трансчеловек - постчеловек (Иуков, 2017: 246-248). Стремление к сверхчеловеку - одна из основных интенций культуры в целом, обусловливающая историческую эволюцию его образа. По этой причине возникновение трансгуманистической версии сверхчеловека является закономерным. Аюбая новая концепция в истории философии и науки является экспансивной. Ее примирение с реальностью и определение места в конкретной дискурсивности определяется как внутренними противоречиями, так и критикой со стороны конкурирующих представлений.

Вместе с тем необходимо понимать, что достижение состояния сверхчеловека технологическими средствами неизбежно будет соответствовать системе распределения в современном обществе потребления: «все будет у всех, когда это будет никому не нужно» (Ж. Бодрийяр). Как справедливо утверждает В. И. Аршинов, «расширение человека» (human enhancement) «...даст значительные преимущества тем, для кого эти технологии станут доступнылми» (Аршинов, 2013: 102; курсив мой. - В. А.).

С философско-антропологических позиций результатом достижения состояния сверхчеловека является оптимальный синтез реализации как предназначения человека, так и его насущных задач. Понимание двух вышеназванных элементов входит в число основных задач философской антропологии (см., напр.: Вальверде, 2000: 13). Очевидно, что трансгуманистическая антропология акцентирует внимание лишь на насущных задачах человека, которые ее представители видят в обеспечении выживания Homo sapiens как вида (Нестеров, 2013: 187) или сохранения его разума (Аубровский, 2013: 244). И поскольку вопрос о предназначении человека трудно обойти, трансгуманизм предлагает их отождествить: выживание и предназначение человека суть одно и то же.

Подобное понимание возможно логически, но заметно обедняет образ человека в онтологическом и аксиологическом аспектах. $\mathrm{C}$ позиций пирамиды потребностей А. Маслоу сведение существования человека к обеспечению безопасности (т. е. к биологическому выживанию собственного вида и (или) сохранению разума) - крайне спорная посылка для любой версии антропологии, в том числе и сциентистской. А поскольку стремление радикально и быстро «переделать» «несовершенного человека» 
может привести к непоправимым ошибкам, то ответ трансгуманизма на вопрос: «куда идти человеку?» оказывается односторонним в методологическом аспекте, рискованным в онтологическом и сомнительным в аксиологическом.

\section{ИТОГОВЫЙ ТЕЗИС И ЕГО ОСМЫСАЕНИЕ}

Аля подведения итогов по первой задаче следует синтезировать три рассмотренных тезиса в один: человек есть разум, который может и должен изменить себя (технологическими средствами). На основе проведенного анализа очевидно, что данное утверждение правомерно рассматривать как сииентистский платонизм, отвергающий аристотелистскую традицию в понимании человека. Это вдвойне удивительно, поскольку после Платона любые исторические формы платонизма (например, христианство, неоплатонизм Н. Кузанского, И. Кант, В. С. Соловьев) заимствуют для построения собственных концептуальных систем элементы аристотелизма.

Аля трансгуманистической антропологии движение «назад к Платону», к «рафинированному платонизму», очищенному от всех (или практически всех) элементов аристотелизма, есть логическое следствие тезиса «человек есть разум». Отрицание трансгуманизмом представлений о биосоциальной природе человека фундируется стремлением отвергнуть центральный тезис аристотелизма в философской антропологии: человек есть двуединство души и тела, которые неравноценны, но одинаково необходимы для формирования природы человека.

\section{АНТРОПОАОГИЯ ТРАНСГУМАНИЗМА В КОНТЕКСТЕ АИАИОГА ПААТОНИЗМА И АРИСТОТЕАИЗМА}

Аанный вывод позволяет перейти к оценке значения философско-антропологических оснований трансгуманизма для сциентистской антропологии и современного антропологического дискурса в целом (вторая задача).

В контексте сциентистской антропологии трансгуманизм выступает принципиальным оппонентом биоконсерватизма, который стремится сохранить «естественного (природного) человека» (Ф. Фукуяма, Ю. Хабермас, П. С. Гуревич, В. А. Кутырев, И. В. Черникова). Сущность полемики трансгуманизма и биоконсерватизма возможно выразить словами Ф. Ницше: «Самые заботливые вопрошают: “Как сохраниться человеку?" Заратустра же спрашивает... “Как превзойти человека? ”» (Ницше, 2014: 305; курсив источника. - В. А.). Позиция «заботливых» соответствует биоконсерватизму, а позиция ницшеанского Заратустры выражает точку зрения трансгуманизма. Центральный тезис трансгуманизма о том, что человек есть разум, который может и должен изменить себя (технологическими средствами), критикуется в различных версиях биоконсерватизма.

Поскольку разбор биоконсервативных аргументов против приведенных тезисов антропологии трансгуманизма не входит в число задач статьи, то центральное утверждение биоконсерватизма следует сформулировать в виде тезиса: человек есть телесный разум, который может, но не обязательно должен изменить себя (технологическими средствами). Аанное утверждение выражает позицию умеренного биоконсерватизма, который признает терапевтическое значение конвергентных (NBIC) технологий, но отрицает их использование в качестве средств улучшения человеческой природы. Радикальный биоконсерватизм занимает крайнюю алармистскую позицию: человек есть телесный разум, который может, но категорически не должен изменить себя (технологическими средствами). 
С философско-антропологических позиций важно осознавать, что дискуссия между трансгуманистическим и биоконсервативным пониманием человека есть современный вариант диалога платонизма и аристотелизма. Очевидна односторонность философско-антропологических оснований трансгуманизма, которую возможно выразить формулой «назад к Платону». Подобное мышление есть оригинальное направление движения мысли в контексте постмодернистского стремления «низвергнуть платонизм» (Ж. Аелёз). Однако выявленный ход мысли закономерен в стремлении размежеваться с аристотелизмом, с позиций которого в биоконсерватизме ведется защита «естественного (природного) человека». Подобную ситуацию правомерно рассматривать как вызов сциентистской антропологии, традиционно фундируемой аристотелизмом. В этой связи логично предположить, что в будущем предстоит критический пересмотр антропологических оснований трансгуманизма под давлением критики со стороны биоконсерватизма.

Однако значение трансгуманистических представлений о человеке в современном антропологическом дискурсе выходит за рамки сциентистской антропологии. Ауалистический характер антропологии трансгуманизма, возможно, свидетельствует о кризисе в антропологии и необходимости обновления ее оснований. Неслучайно трансгуманистические представления рассматриваются как потенциальная основа идеологии нового социального порядка (Нестеров, 2013). Интерес трансгуманизма к таким проблемам, как природа человека, его предназначение, бессмертие, идентичность и смысл жизни, указывает на то, что трансгуманистические представления о человеке актуальны для антропологического дискурса современности в целом.

Оценивая перспективы трансгуманизма в названном контексте, следует прибегнуть к исторической аналогии. В первой половине XX в. сциентистско-метафизический платонизм Н. Ф. Федорова преодолевается в аристотелистском синтезе В. И. Вернадского. Последний выходит за рамки сциентизма и способствует утверждению человека в соответствии с обновленным - ноосферным - пониманием гуманизма. Технократический оптимизм начала $\mathrm{XX}$ в., возникший на основе восхищения перспективами новейших технологий данного периода, не в полной мере оправдывается.

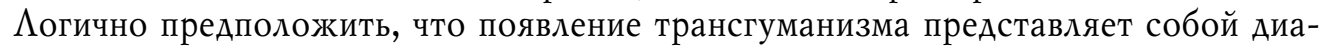
лектическое возвращение сциентистско-метафизического платонизма русского космизма на новом витке спирали развития философии. Вероятно, что и в данном случае технократический оптимизм окажется не вполне обоснованным. Основанием предлагаемой аналогии выступает сциентистский характер основных постулатов русского космизма и трансгуманизма. Их общность в существенном признаке, а также его комплексный характер повышают достоверность аналогии и делают полученный вывод более вероятным.

\section{ЗАКАЮЧЕНИЕ}

Таким образом, трансгуманизм не следует рассматривать только как «технологии свихнувшегося разума» (Гуревич, 2012) или как проявление «времени Mortido» (влечения к смерти) (Кутырев, 2011). Его возникновение в современном антропологическом дискурсе закономерно в контексте представлений постнеклассической картины мира (Магомедов, 2014). Однако следует обратить внимание на концептуальную неполноту трансгуманизма, который представляет собой «рафинированный платонизм», стремящийся защитить «тезис о человеческой исключительности» (Шеффер, 
2010) путем элиминации аристотелистской традиции постижения человека. Названная односторонность, вероятнее всего, будет преодолена в дальнейшем развитии антропологического дискурса. Наиболее вероятный путь этого преодоления - продуктивный и взаимообогащающий диалог трансгуманистической антропологии с аристотелевской традицией в понимании человека.

\section{ПРИМЕЧАНИЕ}

1 Объекты, наделенные признаками субъектности.

\section{СПИСОК АИТЕРАТУРЫ}

Аршинов, В. И. (2013) Конвергентные технологии (НБИКС) и трансгуманистические преобразования в контексте парадигмы сложностности // Глобальное будущее 2045. Конвергентные технологии (НБИКС) и трансгуманистическая эволюция / под ред. А. И. Аубровского. М. : Издательство МБА. С. 94-106.

Барышников, П. Н. (2013) Типология бессмертия в теоретическом поле французского трансгуманизма // Глобальное будущее 2045. Конвергентные технологии (НБИКС) и трансгуманистическая эволюция / под ред. А. И. Аубровского. М. : Издательство МБА. С. 203-227.

Бубер, М. (1995) Проблема человека // Ава образа веры / под ред. П. С. Гуревича, С. Я. Аевит, С. В. Аёзова. М. : Республика. С. 158-232.

Вальверде, К. (2000) Философская антропология. М. : Христианская Россия. 411 с.

Глобальное будущее 2045. Конвергентные технологии (НБИКС) и трансгуманистическая эволюция (2013) / под ред. А. И. Аубровского. М. : Издательство МБА. 272 с.

Гуревич, П. С. (2012) Технологии свихнувшегося разума // Человек и его будущее: Новые технологии и возможности человека / отв. ред. А. Г. Белкина. М. : $\Lambda$ ЕНАНА. С. 355-372.

Гуревич, П. С. (2013) Векторы современного постижения человека // Философский журнал. № 2. С. 95-106.

Аёмин, И. В. (2013) Гуманизм и трансгуманизм: проблема соотношения // Глобальное будущее 2045. Конвергентные технологии (НБИКС) и трансгуманистическая эволюция / под ред. А. И. Аубровского. М. : Издательство МБА. С. 193-202.

Аубровский, А. И. (2013) Природа человека, антропологический кризис и кибернетическое бессмертие // Глобальное будущее 2045. Конвергентные технологии (НБИКС) и трансгуманистическая эволюция / под ред. А. И. Аубровского. М. : Издательство МБА. С. 237-252.

Желнин, А. И. (2016) Идея «биологической недостаточности» человека как фундамент трансгуманизма и ее критический анализ // Научно-технические ведомости Санкт-Петербургского государственного политехнического университета. Гуманитарные и общественные науки. № 3 (250). С. 86-92.

Койре, А. (1985) Платонизм и аристотелизм в средневековой философии // Койре, А. Очерки истории философской мысли: О влиянии философских концепций на развитие научных теорий. М. : Прогресс. С. 51-73.

Кутырев, В. А. (2011) Время Mortido // Вопросы философии. № 7. С. 18-29.

$\Lambda$ атур, Б. (2006) Нового Времени не было. Эссе по симметричной антропологии. СПб. : ИзАательство Европейского университета в Санкт-Петербурге. 240 с.

Иуков, В. А. (2017) Трансгуманизм // Знание. Понимание. Умение. № 1. С. 245-252. DOI: 10.17805/zpu.2017.1.20.

Магомедов, К. М. (2014) Случайность - это характеристика объективных процессов или феномен человеческой экзистенции? // Гуманитарные, социально-экономические и общественные науки. № 1. С. 52-54.

Назаретян, А. П. (2013) Мировоззренческая перспектива планетарной цивилизации // Глобальное будущее 2045. Конвергентные технологии (НБИКС) и трансгуманистическая эволюция / под реА.А. И. Аубровского. М. : Издательство МБА. С. 26-48. 
Нестеров, А. Ю. (2013) Проблема человека в свете идеологии эволюционного трансгуманизма // Глобальное будущее 2045. Конвергентные технологии (НБИКС) и трансгуманистическая эволюция / под ред. А. И. Аубровского. М. : Издательство МБА. С. 183-192.

Ницше, Ф. (2014) Так говорих Заратустра. Книга для всех и ни для кого. СПб. : Аениздат ; «Команда A». 352 с.

Платон (1990) Алкивиад I // Платон. Собрание сочинений : в 4 т. М. : Мысль. Т. 1. C. $220-267$.

Платон (1993) Федон // Платон. Собрание сочинений : в 4 т. М. : Мысль. Т. 2. С. 7-80.

Фукуяма, Ф. (2004) Наше постчеловеческое будущее: Последствия биотехнологической революции : пер. с англ. М. : АСТ, $\Lambda$ ЮС. 349 с.

Хабермас, Ю. (2002) Будущее человеческой природы. На пути к либеральной евгенике? М. : Весь мир. 144 с.

Человек и его будущее: Новые технологии и возможности человека (2012) / отв. ред.

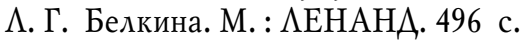

Черникова, И. В. (2016) Сохранение природы человека как глобальная проблема современности // Вопросы философии. №9. С. 36-43.

Шеффер, Ж.-М. (2010) Конец человеческой исключительности. М. : Новое литературное обозрение. 392 с.

Щербаков, В. П. (2016) От техник тела к техникам разума // Вестник Иенинградского государственного университета им. А. С. Пушкина. № 3. С. 118-126.

Эпштейн, М. Н. (2009) Творческое исчезновение человека // Философские науки. №2. C. $91-105$.

Laта поступления: 30.05.2017 2.

\section{TRANS-HUMANISTIC PERCEPTIONS OF A HUMAN BEING IN CONTEMPORARY ANTHROPOLOGICAL DISCOURSE \\ V. A. DOLIN \\ Belgorod LAW INSTITUTE NAMED AFTER I. D. PutILIN, MINISTRY OF INTERNAL AFFAIRS OF THE RUSSIAN FEDERATION}

The article deals with philosophical and anthropological foundations of trans-humanism and evaluates their implication for scientistic anthropology and contemporary anthropological discourse in general. The dialogue between Platonic and Aristotelian traditions in philosophical anthropology as well as the triad of «structure - functioning - development» is regarded as the methodological basis for the analysis.

Philosophical foundations of trans-humanism are formulated in three theses: a human being is a mind; a human being is an open being, able to change their own nature; the ultimate goal of human transformation is an achievement of superhuman condition. The theses are evaluated from bio-conservative points of view.

In general, a human being in trans-humanism is a mind which can and must change themself (by means of technology). Such an understanding of a human being is scientistic Platonism. Trans-humanist denial of ideas on biosocial nature of human being is based on the desire to reject the central thesis of Aristotelian philosophical anthropology: a human being is a duality of body and soul. They are unequal, but equally necessary for the formation of human nature.

In context of scientistic anthropology trans-humanism acts as a principal opponent of bio-conservatism that seeks to preserve «a natural human being». In contemporary anthropological discourse, trans-humanism represents a dialectical return to scientistic and metaphysical Platonism of Russian cosmism. It is likely that technocratic optimism will not be completely justified in this case.

The trans-humanistic anthropology in conceptual aspect is a «refined Platonism», which rejects the Aristotelian tradition of comprehension of a human being. The emergence of trans-humanism in contemporary anthropological discourse is inevitable. A conclusion is drawn about the possibility of 
critical review of anthropological foundations of trans-humanism. It will be substantiated by productive and mutually enriching dialogue between trans-humanistic anthropology and the Aristotelian tradition in perception of a human being.

Keywords: trans-humanism; bio-conservatism; human nature; human essence; Platonism; Aristotelism; superhuman; NBIC-convergence; convergent technologies; post-human

\section{REFERENCES}

Arshinov, V. I. (2013) Konvergentnye tekhnologii (NBIKS) i transgumanisticheskie preobrazovaniia v kontekste paradigmy slozhnostnosti. In: Global'noe budushchee 2045. Konvergentnye tekbnologii (NBIKS) i transgumanisticheskaia evoliutsiia / ed. by D. I. Dubrovsky. Moscow, MBA Publ. Pp. 94-106. (In Russ.).

Baryshnikov, P. N. (2013) Tipologiia bessmertiia v teoreticheskom pole frantsuzskogo transgumanizma. In: Global' noe budushchee 2045. Konvergentnye tekbnologii (NBIKS) i transgumanisticheskaia evoliutsiia/ ed. by D. I. Dubrovsky. Moscow, MBA Publ. Pp. 203-227. (In Russ.).

Buber, M. (1995) Problema cheloveka. In: Dva obraza very / ed. by P. S. Gurevich, S. Ia. Levit and S. V. Lezov. Moscow, Republic Publ. Pp. 158-232. (In Russ.). Russ.).

Val'verde, K. (2000) Filosofskaia antropologiia. Moscow, Christian Russia Publ. 411 p. (In

Global'noe budushchee 2045. Konvergentnye tekbnologii (NBIKS) i transgumanisticheskaia evoliutsii (2013)/ ed. by D. I. Dubrovsky. Moscow, MBA Publ. 272 p. (In Russ.).

Gurevich, P.S. (2012) Tekhnologii svikhnuvshegosia razuma. In: Chelovek $i$ ego budushchee: Novye tekhnologii $i$ vozmozhnosti cheloveka / ed. by L. G. Belkina. Moscow, LENAND Publ. Pp. 355-372. (In Russ.).

Gurevich, P. S. (2013) Vektory sovremennogo postizheniia cheloveka. Filosofskii zburnal, no. 2, pp. 95-106. (In Russ.).

Demin, I. V. (2013) Gumanizm i transgumanizm: problema soot-nosheniia. In: Global'noe budushcbee 2045. Konvergentnye tekbnologii (NBIKS) i transgumanisticheskaia evoliutsiia / ed. by D. I. Dubrovsky. Moscow, MBA Publ. Pp. 193-202. (In Russ.).

Dubrovskii, D. I. (2013) Priroda cheloveka, antropologicheskii krizis i kiberneticheskoe bessmertie. In: Global'noe budushchee 2045. Konvergentnye tekbnologii (NBIKS) i transgumanisticheskaia evoliutsiia/ ed. by D. I. Dubrovsky. Moscow, MBA Publ. Pp. 237-252. (In Russ.).

Zhelnin, A. I. (2016) Ideia «biologicheskoi nedostatochnosti» cheloveka kak fundament transgumanizma i ee kriticheskii analiz. Nauchno-tekbnicheskie vedomosti Sankt-Peterburgskogo gosudarstvennogo politekbnicheskogo universiteta. Gumanitarnye i obshchestvennye nauki, no. 3 (250), pp. 86-92. (In Russ.).

Koyre, A. (1985) Platonizm i aristotelizm v srednevekovoi filosofii. In: Koyre A. Ocherki istorii filosofskoi mysli: O vliianii filosofskikb kontseptsii na razvitie nauchnykb teorii. Moscow, Progress Publ. Pp. 51-73. (In Russ.).

Kutyrev, V. A. (2011) Vremia Mortido. Voprosy filosofii, no. 7, pp. 18-29. (In Russ.).

Latur, B. (2006) Novogo Vremeni ne bylo. Esse po simmetricbnoi antropologii. St. Petersburg, The Publishing House of the European University in St. Petersburg. 240 p. (In Russ.).

Lukov, V. A. (2017) Transgumanizm. Znanie. Ponimanie. Umenie, no. 1, pp. 245-252. (In Russ.). (IN Russ.). DOI: 10.17805/zpu.2017.1.20.

Magomedov, K. M. (2014) Sluchainost' - eto kharakteristika ob»ektivnykh protsessov ili fenomen chelovecheskoi ekzistentsii? Gumanitarnye, sotsial' no-ekonomicheskie i obshchestvennye nauki, no. 1, pp. 52-54. (In Russ.).

Nazaretian, A. P. (2013) Mirovozzrencheskaia perspektiva planetarnoi tsivilizatsii. In: Global' noe budushchee 2045. Konvergentnye tekbnologii (NBIKS) i transgumanisticheskaia evoliutsiia / ed. by D. I. Dubrovsky. Moscow, MBA Publ. Pp. 26-48. (In Russ.).

Nesterov, A. Iu. (2013) Problema cheloveka v svete ideologii evoliutsionnogo transgumanizma. In: Global' noe budushchee 2045. Konvergentnye tekbnologii (NBIKS) i transgumanisticheskaia evoliutsiia/ ed. by D. I. Dubrovsky. Moscow, MBA Publ. Pp. 183-192. (In Russ.). 
Nitsshe, F. (2014) Tak govoril Zaratustra. Kniga dlia vsekb i ni dlia kogo. St. Petersburg, Lenizdat Publ., Team A Publ. 352 p. (In Russ.).

Platon. (1990) Alkiviad I, 130s. In: Sobranie socbinenii : in 4 vol. Moscow, The idea Publ. Vol. 1. Pp. 220-267. (In Russ.).

Platon. (1993) Fedon, 82e. In: Sobranie socbinenii : in 4 vol. Moscow, The idea Publ. Vol. 2. Pp. 7-80. (In Russ.).

Fukuiama, F. (2004) Nashe postchelovecheskoe budushchee: Posledstviia biotekbnologicheskoi revoliutsii. Moscow, AST Publ., Luxe Publ. 349 p. (In Russ.).

Khabermas, Iu. (2002) Budushchee chelovecheskoi prirody. Na puti k liberal' noi evgenike? Moscow, All world Publ. 144 p. (In Russ.).

Chelovek $i$ ego budushchee: Novye tekbnologii $i$ vozmozhnosti cheloveka (2012) / ed. by L. G. Belkina. Moscow, LENAND Publ. 496 p. (In Russ.).

Chernikova, I. V. (2016) Sokhranenie prirody cheloveka kak glo-bal'naia problema sovremennosti. Voprosy filosofii, no. 9, pp. 36-43. (In Russ.).

Sheffer, Zh.-M. (2010) Konets chelovecheskoi iskliuchitel'nosti. Moscow, New literary review Publ. 392 p. (In Russ.).

Shcherbakov, V. P. (2016) Ot tekhnik tela k tekhnikam razuma. Vestnik Leningradskogo gosudarstvennogo universiteta im. A. S. Pusbkina, no. 3, pp. 118-126. (In Russ.).

Epshtein, M. N. (2009) Tvorcheskoe ischeznovenie cheloveka. Filosofskie nauki, no. 2, pp. 91-105. (In Russ.).

Submission date: 30.05.2017.

Аолин Вячеслав Александрович - кандидат философских наук, доцент кафедры гуманитарных и социально-экономических дисциплин Белгородского юридического института Министерства внутренних дел Российской Федерации им И. А. Путилина. Адрес: 308024, Россия, г. Белгород, ул. Горького, д. 71. Тел.: +7 (4722) 55-71-26. Эл. адрес: v.a.dolin@mail.ru

Dolin Vyacheslav Aleksandrovich, Candidate of Philosophy, Associate Professor, Department of the Humanitarian, Social and Economic Sciences, Belgorod Law Institute named after I. D. Putilin, Ministry of the Internal Affairs of the Russian Federation. Postal address: 71, Gorkogo St., Belgorod, Russian Federation 308024. Tel./fax: +7 (4722) 55-71-26. E-mail: v.a.dolin@mail.ru 